\title{
SUSTAINABLE WINE AND GRAPE PRODUCTION, THE EXAMPLE OF HUNGARY
}

\section{Edit llona Pallás}

\author{
Eszterházy Károly Egyetem, Gyöngyösi Károly Róbert Campus
}

Before analysing the economic situation of winegrape production, it is practical to mention some issues concerning the industry. Grape production in Hungary suffered a severe crisis in the 1990's regarding both production and sales. Its consequence is the decreasing area of grape production and the reducing number of grape producers. Lately, after our EU accession the grape and wine verticum has significantly improved. The situation is still grave today as the producers have to face the more and more intense competition in the market and cheap import products both on the national and international markets. Grape production is in a more disadvantaged situation than wine making and the risks are higher. We have to know the cost-profit situation of the well-discernible verticum parts to make recommendations. Despite the changes, the great fluctuation in income is typical for the industry. Grape is one of the plants where price often did not cover costs in the consecutive years. Costs of production cannot be assessed on their own. They can be judged in relation with the yield changes in real.

Keywords: sustainability, wine and grape production, cost of wine grape, selling price of wine

\section{Introduction}

The environmental resource scarcity issues are entirely real. As a result of climate changes, most agricultural patterns may become disrupted and the poorest countries are the most vulnerable to such disruptions (Magda, 2013).

The (over] exploitation of our entire ecosystem and the depletion of natural resources (the reserve-to-production ratio of oil reserves is rapidly declining) carry a price that must be paid today to compensate future generations for the losses (or costs of substitution) they will face tomorrow (Magda, 2012).

Hungary's natural and ecological endowments are favourable for producing wine grapes. The wine and grape industry could be an important part of agriculture from the point of view of employment and value creation. Due to its role in tourism and its opportunities for export, the industry can be regarded as one of the industries to be strategically developed (DUPCSÁK et al., 2011).

The present situation is not favourable because of the gradual decrease of vineyards although there has been a spectacular progress lately (Béládi and Szili, 2015). To date, the total area of vineyards hardly exceeds 80 thousand hectares and almost all the areas of the industry need to be reshaped. Agricultural policy, such as the reorganisation of wine communities, the making of the law on wine, the investment and production support as well as well-prepared specialists played a great role in changes.

\section{Material and methods}

In the following sessions, the paper focuses on the characteristics of the Hungarian wine production, which means different opportunities in production and consumption of the wine.

The methodological approach is mainly descriptive. The analysis will be based on relevant statistical data from secondary sources from national and international literature.

\section{Results and discussion}

Natural resources form part of the natural environment that meets human demands. The depletion of them both globally and locally - thus in case of
Hungary too - has become a realistic issue, therefore sustainable development has become the most complex challenge in the history of mankind for the next decades. It exists at macro-, micro- and individual levels and resulted in the intertwining of social, economic and ecological issues. It is advisable to follow a new paradigm in the course of natural resources management that is based on the trinity of sustainability - climate change - globalization. Sustainability can only be asserted in this harmony.

The local program of sustainable development (Local Agenda 21 - "LA $21^{\prime \prime}$ ) aims to create harmony at local and micro-regional level in the natural environment-economy-society triangle in a way that it serves the long-term principles of sustainability.

\section{The characteristics of Hungary's grape production}

The total area of the vineyards has been decreasing significantly. As a result, yield will not be able to meet the minimum requirements of the wine industry, either. Such an amount of grapes should be grown that would ensure the production of 3.5-4 million $\mathrm{hl}$ wine. The efficiency of yield per hectare is low in Hungary and with an average yield of $5-7 \mathrm{t} \mathrm{ha}^{-1}$ we cannot be competitive.

If Hungary would like to regain its market segment of mass-produced wines, the yield of the vineyards must be increased. Sidlovits and Kator (2015) state that the average yield of the vineyards in Hungary is $41 \mathrm{hl} \mathrm{ha}^{-1}$ while in the case of GNM (geographically non-marked) wines it is $60 \mathrm{hl} \mathrm{ha}^{-1}$. In contrast, in Italy it is $74 \mathrm{hl} \mathrm{ha}^{-1}$ and $116 \mathrm{hl} \mathrm{ha}^{-1}$ for the geographically nonmarked types, respectively. The technology, mechanisation and production organisation of the Italian producers are better than the Hungarian ones and in many cases they irrigate. Where possible, irrigation is inevitable as it makes us competitive in the GNM segment.

According to Nagy, Kovács and Varga (2010) the Hungarian practice is not good. There is no balance of power among the grape producers, viticulturists and commercial units. Consequently, between the certain stages the share of profit is uneven. Grape producers may incur losses as they can be significant in weaker years. This would contribute to area loss and that is why many take part in felling programmes. The characteristics of grape production are presented by Table 1.

The Agricultural Economic Research Institute (AERI) runs a testing system to analyse the cost-income relations of the industries similarly to the 
Table 1 The characteristics of grape production in Hungary

\begin{tabular}{|l|c|c|c|}
\hline Name & 2011 & 2012 & 2013 \\
\hline Harvested total grape yield, tonnes & 449870 & 356363 & 451115 \\
\hline Total grape producing area, hectare & 81001 & 82274 & 80193 \\
\hline Product yield, $\mathrm{kg} \mathrm{ha}^{-1}$ & 5960 & 4930 & 6510 \\
\hline Grapes for consumption, tonnes & 14634 & 12563 & 15196 \\
\hline Purchasing average price, $\mathrm{Ft} \mathrm{kg}^{-1}$ & & & 198 \\
\hline Dessert grape & 149 & 100 & 159 \\
\hline Wine grape & 85 & & 112 \\
\hline Producer-market average price, Ft kg- & & \\
\hline Dessert grape (for consumption) & 315 & 428 & 355 \\
\hline Gross production value (dessert grape) million Ft & & & 2319 \\
\hline Current value & 2568 & 2203 & 2319 \\
\hline Comparative price (last year) & 3479 & & \\
\hline
\end{tabular}

Source: Central Statistical Office (CSO), Yearbook of Agricultural Statistics, 2013

Table 2 The cost and income situation of wine grape

\begin{tabular}{|c|c|c|c|c|}
\hline \multirow[t]{2}{*}{ Name } & \multirow[t]{2}{*}{ Measurement } & \multicolumn{3}{|c|}{ Average yield of prominent farms } \\
\hline & & 2011 & 2012 & 2013 \\
\hline Production cost & HUF ha-1 & 608298 & 571159 & 656820 \\
\hline Average yield & tha $^{-1}$ & 7.28 & 5.38 & 8.31 \\
\hline First cost & HUF $^{-1}$ & 83526 & 106919 & 79021 \\
\hline Selling price & HUF $^{-1}$ & 90659 & 110365 & 111439 \\
\hline Specific income* & HUF $^{-1}$ & 7133 & 3446 & 32418 \\
\hline Industrial revenue ${ }^{* *}$ & HUF ha-1 & 194220 & 170101 & 418460 \\
\hline Industrial revenue per $100 \mathrm{Ft}$ production cost & HUF & 31.93 & 29.78 & 63.71 \\
\hline
\end{tabular}

Source: Calculations made on the basis of the testing system by the Industrial Economic Department of AERI, In Béládi and Szili, 2015 Note: ${ }^{*}$ without support, ${ }^{* *}$ with support

Table 3 The cost and income situation of wine grape, 2013

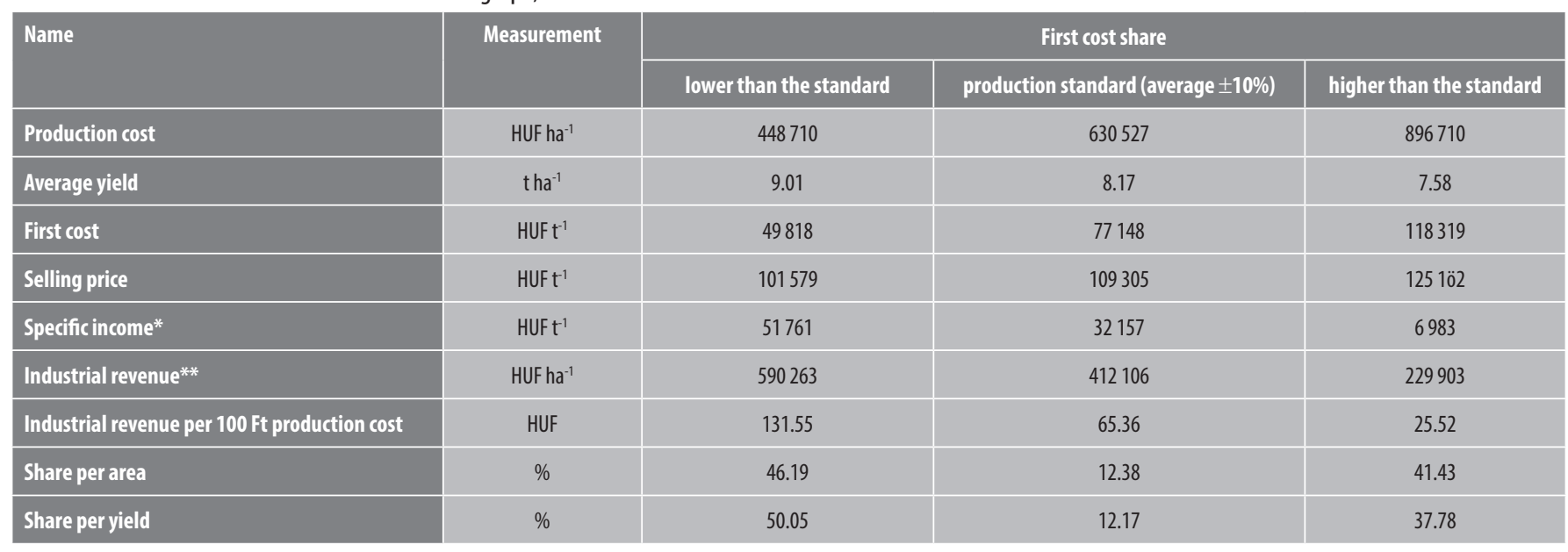

Source: Calculations made on the basis of the testing system by the Industrial Economic Department of AERI, In Béládi and Szili, 2015

Note: * without support, ${ }^{* *}$ with support

European practice. Data are collected in a database and conclusions may be drawn from the figures collected this way (Béládi and Szili, 2015).

Wine grape production incurs significant costs. Two-thirds are made up by wages and salaries, pesticides and machinery. The revenue of the industry is appropriate only if support is given (Table 2).
From the point of view of the first cost the grape producing farms show significant differences. Farms that have a deviation of $\pm 10 \%$ from the average of the total sample are the standard while the other farms are classified with lower or higher values than the average. It is illustrated by Table 3. 
Table 4 Grape and wine production

\begin{tabular}{|c|c|c|c|c|c|c|c|}
\hline \multirow[t]{2}{*}{ Name } & \multirow{2}{*}{$\begin{array}{c}2001-2005 \\
\text { average }\end{array}$} & \multirow{2}{*}{$\begin{array}{c}2006-2010 \\
\text { average }\end{array}$} & \multirow[t]{2}{*}{2011} & \multirow[t]{2}{*}{2012} & \multicolumn{3}{|c|}{ Of which } \\
\hline & & & & & business organisation & private farms & $\mathrm{N} / \mathrm{A}$ in business \\
\hline Vineyard, thousand ha & 92 & 82 & 81 & 82 & 13 & 55 & 14 \\
\hline - of which: production area & - & 75 & 76 & 72 & 12 & 48 & 13 \\
\hline Grape yield, thousand t & 632 & 496 & 450 & 356 & 65 & 233 & 58 \\
\hline - of which: dessert grape & 27 & 16 & 15 & 13 & 0 & 12 & 1 \\
\hline Average yield on the production area, $\mathrm{kg} \mathrm{ha}^{-1}$ & 7080 & 6570 & 5960 & 4930 & 5440 & 4870 & 4660 \\
\hline Wine production, million I & 420 & 298 & 282 & 224 & - & - & - \\
\hline
\end{tabular}

Source: CSO, 2013

Grape production is significant in the Veszprém, Baranya and Tolna counties in Transdanubia, the Heves and Borsod-AbaújZemplén counties in North Hungary, while the Bács-Kiskun county is the leading one in the Great Plain.

Regarding yield, 2010 marked the lowest point and since then there has been a slight increase.

Grape and wine production is typical for private farms as the area of business organisations has decreased. It is illustrated by Table 4. AERI classifies primary producers, private farmers, family farms and joint farms under the term private farm in line with the practice of the CSO. Joint farms are made up by several primary producers and private farms under common control in practice as if it were an enterprise with independent management. All the other business forms are listed as joint organisations.

\section{Characteristics of wine production, export-import and processing selling prices}

It is our most important task to preserve the dominance of the Hungarian wine in the domestic market. Today, the presence of import wines is disturbing on the market (Farkas, 2010a).

In ten years' time wine and grape production has produced weak results-only the past few years are promising. Significant felling, change in technology and inadequate plantation resulted in its decreasing role in employment to a great extent (Barócsi et al., 2012). The regional characteristics of wine and grape production are presented by Table 5 .

Our production does not even reach 3 million hl, which is necessary for domestic consumption. The regional characteristics are similar to the ones of the vineyards and most wines are produced in the Bács-Kiskun county.

In the case of wine the role of commerce is decisive for revenue. Acceding to the classical commercial theories, the differences between productivity and production cost of countries induce trade. However, different forms of intervention in the trade of agricultural products (restrictions on quantity or price regulation) modify the prevalence of advantages in competitiveness (Bozsik, 2003).

The reasons for influencing the market differ (stabilising the market, ensuring decent income, satisfying consumers' demand) but

Table 5 The regional characteristics of wine and grape production in Hungary (2013)

\begin{tabular}{|c|c|c|c|c|}
\hline \multirow[t]{3}{*}{ Region } & \multicolumn{3}{|c|}{ Grape } & \multirow{3}{*}{$\begin{array}{c}\text { Wine } \\
\text { production, hl }\end{array}$} \\
\hline & \multicolumn{2}{|c|}{ yield, $\mathbf{t}$} & \multirow{2}{*}{$\begin{array}{l}\text { average, } \\
\text { yield kg ha-1 }\end{array}$} & \\
\hline & total & of which: dessert grape & & \\
\hline Central Hungary & 21218 & 405 & 6340 & 137375 \\
\hline Central Transdanubia & 52788 & 913 & 5890 & 330769 \\
\hline West Transdanubia & 26370 & 645 & 4700 & 174052 \\
\hline South Transdanubia & 80008 & 3992 & 7140 & 524855 \\
\hline North Hungary & 116761 & 4606 & 7030 & 768856 \\
\hline North Great Plains & 14138 & 1986 & 4700 & 83989 \\
\hline South Great Plains & 139833 & 2650 & 6800 & 924261 \\
\hline Total & 451115 & 15196 & 6510 & 2944158 \\
\hline
\end{tabular}

they should be considered in trade. Our country can consider and assess these factors due to their weight in wine trade and competitiveness (Bozsik, 2005).

Since Hungary's EU accession, importing wines has dramatically been increasing and basically it is the Italian wines that dominate. Import is partly loose wine. The price of the Hungarian wines which are geographically not marked is relatively high and similar to the price of the French wines. Other competitors sell this category cheaper (Italy, Spain).

To regain the competitiveness of the Hungarian wines, a more efficient production organisation is necessary. Such a complex subsidising and controlling system is necessary that embraced the entire product path from producing raw materials to marketing wines (Sidlovits et al., 2012).

The amount and value of export and import are presented by Table 6 and Table 7 .

In the export Germany, Slovakia, the Czech Republic, the United Kingdom, Lithuania and Poland are the most important destinations while the Italian mass-produced wines lead in import. Regarding prices there is a continuous increase in all categories, which can result in even 10-15\% price rise per year (Table 8).

Farkas (2010b.) examines the competitiveness of different wine categories. The Relative Trade Advantage (RTA) index takes both import and export into consideration.

Based on the examination, the RTA values showed positive results except for the red quality loose wine.

Bozsik (2008) also qualified quality white bottled wines competitiveness. The CMS method (Constant Market Share Analysis) used in his examination is suitable to define three structural components of market share (market size effect, market composition effect, competitiveness). A large part of Hungarian wineries still work without strategic objectives. 
Table 6 Hungary's foreign trade of wine in quantity

\begin{tabular}{|c|c|c|c|c|c|c|c|}
\hline \multirow[t]{2}{*}{ Type } & \multirow[t]{2}{*}{ Wine category } & \multicolumn{3}{|c|}{ Amount of export } & \multicolumn{3}{|c|}{ Amount of import } \\
\hline & & 2013, thousand hl & 2014 , thousand $\mathrm{hl}$ & change, $\%$ & 2013, thousand hl & 2014 , thousand $h l$ & change, $\%$ \\
\hline \multirow{3}{*}{ Bottled } & white & 111.11 & 154.26 & 138.84 & 16.64 & 14.87 & 89,34 \\
\hline & red and rosé & 70.26 & 92.25 & 131.30 & 30.38 & 31.78 & 104,62 \\
\hline & total & 181.37 & 246.51 & 135.92 & 47.02 & 46.65 & 99,21 \\
\hline \multirow[t]{2}{*}{ Loose } & red and rosé & 30.52 & 30.88 & 101.20 & 169.73 & 207.33 & 122,15 \\
\hline & total & 300.49 & 330.33 & 109.93 & 334.73 & 289.75 & 86,56 \\
\hline \multicolumn{2}{|c|}{ Total of bottled and loose } & 481,86 & 576.84 & 119.71 & 381.76 & 336.40 & 88.12 \\
\hline
\end{tabular}

Source: CSO, Agrimarket Reports, 2015. 5.

Table 7 Hungary's foreign trade of wine in value

\begin{tabular}{|c|c|c|c|c|c|c|c|}
\hline \multirow[t]{2}{*}{ Type } & \multirow[t]{2}{*}{ Wine category } & \multicolumn{3}{|c|}{ Amount of export } & \multicolumn{3}{|c|}{ Amount of import } \\
\hline & & 2013, bn HUF & 2014 , bn HUF & change, $\%$ & 2013, bn HUF & 2014, bn HUF & change, $\%$ \\
\hline \multirow{3}{*}{ Bottled } & white & 6.06 & 7.98 & 131.80 & 0.69 & 0.79 & 115,40 \\
\hline & red and rosé & 3.42 & 4.17 & 121.91 & 1.70 & 2.09 & 122,58 \\
\hline & total & 9.48 & 12.15 & 128.23 & 2.39 & 2.88 & 120,52 \\
\hline \multirow{3}{*}{ Loose } & white & 6.19 & 6.75 & 108.60 & 2.44 & 0.72 & 29,37 \\
\hline & red and rosé & 0.81 & 0.79 & 96.74 & 2.47 & 1.90 & 76,89 \\
\hline & total & 7.01 & 7.51 & 107.22 & 4.90 & 2.61 & 53,26 \\
\hline \multicolumn{2}{|c|}{ Total of bottled and loose } & 16.48 & 19.66 & 119.30 & 7.29 & 5.49 & 75.31 \\
\hline
\end{tabular}

Source: CSO, Agrimarket Reports, 2015.5.

Table 8 The processing selling price of wines in Hungary

\begin{tabular}{|c|c|c|c|c|c|}
\hline \multicolumn{3}{|l|}{ Name } & 2013 & 2014 & $2014 / 2013 \%$ \\
\hline \multirow{4}{*}{ White } & \multirow{2}{*}{ geographically non-marked } & amount, $\mathrm{hl}$ & 211576 & 220052 & 104,01 \\
\hline & & average price, HUF Ft $\mathbf{~ h l}^{-1}$ & 21001 & 20055 & 95,50 \\
\hline & \multirow{2}{*}{$\begin{array}{l}\text { patented geographically } \\
\text { marked }\end{array}$} & amount, hl & 82339 & 125821 & 152,81 \\
\hline & & average price, HUF Ft ${ }^{-1} \mathbf{h l}^{-1}$ & 28496 & 25101 & 102,12 \\
\hline \multirow{2}{*}{\multicolumn{2}{|c|}{ Total white }} & amount, hl & 293915 & 345873 & 117.68 \\
\hline & & average price, $\mathrm{HUF} \mathrm{Ft}^{-1} \mathrm{hl}^{-1}$ & 23114 & 23346 & 101.00 \\
\hline \multirow{4}{*}{ Red and rosé } & \multirow{2}{*}{ geographically non-marked } & amount, hl & 183159 & 193818 & 105,82 \\
\hline & & average price, $\mathrm{HUF} \mathrm{Ft}^{-1} \mathrm{hl}^{-1}$ & 22868 & 22063 & 96,48 \\
\hline & \multirow{2}{*}{$\begin{array}{l}\text { patented geographically } \\
\text { marked }\end{array}$} & amount, hl & 115945 & 89416 & 77,12 \\
\hline & & average price, $\mathrm{HUF}^{-1} \mathrm{ht}^{-1}$ & 30310 & 30182 & 99,58 \\
\hline \multirow{2}{*}{\multicolumn{2}{|c|}{ Total of red and rosé }} & amount, hl & 299104 & 283234 & 94.69 \\
\hline & & average price, $\mathrm{HUF} \mathrm{Ft}^{-1} \mathrm{hl}^{-1}$ & 25753 & 24626 & 95.62 \\
\hline \multirow{2}{*}{\multicolumn{2}{|c|}{ Total of geographically non-marked wine }} & amount, hl & 394735 & 413869 & 104.85 \\
\hline & & average price, HUF Ft $^{-1} \mathbf{h l}^{-1}$ & 21871 & 20995 & 95.99 \\
\hline \multirow{2}{*}{\multicolumn{2}{|c|}{ Total of patented geographically marked wine }} & amount, hl & 198284 & 215237 & 108.55 \\
\hline & & average price, $\mathrm{HUF} \mathrm{Ft}^{-1} \mathrm{hl}^{-1}$ & 29557 & 29550 & 99.98 \\
\hline \multirow{2}{*}{\multicolumn{2}{|c|}{$\begin{array}{l}\text { Total of geographically non-marked wine and patented } \\
\text { geographically marked wine }\end{array}$}} & amount, hl & 593019 & 629107 & 106.09 \\
\hline & & average price, $\mathrm{HUF} \mathrm{Ft}^{-1} \mathrm{~h}^{-1}$ & 24449 & 23922 & 97.84 \\
\hline
\end{tabular}

Source: AERI PÁIR 2015. 1.

Note: wines produced domestically 
Lehota et al. (2004) state that corporate strategic groups tailored to industrial characteristics have slowly been forming. The authors discussed that the creation of a homogenous strategy is not practical; rather, a differentiated strategy tailored to different conditions would be successful. Social marketing is one of the decisive areas of differentiated industrial strategy.

The last 11 years did not fulfil the dreams of the differentiated strategy envisioned.

To date, a very powerful trend for strategy can be traced down in the wine region of Tokaj financed by the BOR-VIDÉK Tokaj Hegyalja National Programme.

The development of social wine marketing is not spectacular, more funds should be raised and more concerted activities would be required.

According to Gaál (2010), marketing is full of contradictions in the food industry. The conceptual activity organised by AMC can be praised, which, in fact, means the social marketing of MGC. It also has some visible impacts (on our principal partner's, Germany's market), i.e. the growing consumer demand for Hungarian products. In some product paths, industrial cooperation has helped creating high value product positioning (wine, brandy).

The idea of social marketing aroused in the USA after the global economic recession. Farmers made marketing orders and marketing agreements for controlling production and adapting to the market in qualitative and quantitative terms. These organisations were aimed at measuring collective and coordinated supply behaviour of specific products by marketing tools (Totth, 2007).

\section{Summary}

In the national food industry most players in the industry are able to perform limited marketing activities so that is why there is the need for social marketing. According to Totth (2006) social media is such a marketing activity that stretches beyond corporate marketing and performs marketing tasks for a certain industry or producer group together with its participants.

The joint financing of producers and that of state subsidies could lead to success and the activity of social agrimarketing as a part of industrial strategy based on the legally regulated structure and consensus can be successful. Two forms can be mentioned here:

$\square$ societal marketing in which the groups are deliberately formed based on contractual liabilities,

$\square$ social marketing in which group formation can be forced and the entire industry is a part of it.

As far as the international examples are concerned, forced formation is general.

Marketing is necessary for improving the market. Due to the fragmented wine industry, social marketing activities play a great role but the task is complicated. Wine marketing is the collection of marketing science and knowledge on wine, so it is a great challenge for the specialists (Molnár, 2007). The wine profession itself considers the role of marketing important but the intensification of the industrial marketing orientation can hardly be experienced.

Corporate marketing cannot be substituted for social marketing activities and marketing culture and attitude are still not well-established. There is no unified wine brand but the 2011 decree of the government shows the intention of developing wine tourism according to which Agrimarketing Centre that performs social agri-and wine marketing activities will be transferred under the control of Hungarian Tourism Zrt (Harsányi et al., 2014).
However, no significant increase in domestic consumption can be expected. A defensive strategy can be imagined that could try to offset the attacks of partly import wines and partly other national spirits.

It is typical that we can find only forecasts and estimations instead of definite strategies (we have been speaking about agricultural strategy for about 20 years). Without specific goals and definite strategies we will be hopeless, futureless and losers.

\section{References}

BARÓCSI, Z. - DEME, P. - MARSELEK, S. 2012. Szőlő- és bortermelésünk helyzete, fejlesztési lehetőségek. In XXXIV. Óvári Tudományos Nap, Mosonmagyaróvár, 2012, pp. 124-130.

BÉLÁDI, K. - SZILI, V. 2015. A borszőlőtermelés költség- és jövedelemhelyzete. In Agrofórum Extra, 2015, no. 61, pp. 5-7.

B0ZSIK, N. 2003. Az agrártermelés versenyképessége. In Észak-Magyarország agrárfejlesztésének lehetőségei. (szerk.: Magda, S. - Marselek, S.) In Agroinform Kiadó, Budapest, 2003, pp. 39-54.

B0ZSIK, N. 2005. Magyarország és az Európai Unió közötti borkereskedelem elemzése, különös tekintettel a versenyképességre. Doktori étkezés, Szent István Egyetem, Gazdálkodás- és Szervezéstudományok Doktori Iskola, Gödöllö, 2005, p. 141.

B0ZSIK, N. 2008. A magyar borok külkereskedelmi versenyképességének elemzése a konstans piaci részesedés alapján. In XI. Nemzetközi Tudományok Napok, Gyöngyös, 2008, pp. 312-315.

DUPCSÁK, Zs. - KEREK, Z. - MARSELEK, S. 2011. Szőlō- és bortermelés 2011. Évi kilátásai. In Östermelö, gazdálkodók lapja, vol. 15, 2011, no. 2. pp. 61-65. p.

FARKAS, Á. 2010a. A borok versenyképességi elemzése. In XII. Nemzetközi Tudományos Napok, Gyöngyös, 2010, pp. 543-549.

FARKAS, Á. 2010b. A hazai borkategóriák külpiaci versenyképességének értékelése az EU integrációnk utáni időszakban. In XII. Nemzetközi Tudományos Napok, Gyöngyös, 2010, pp. 550-554.

GAÁL, B. 2010. Az élelmiszergazdasági marketing helyzete és lehetőségei Magyarországon. In Gazdálkodás, vol. 54, 2010, no. 6, pp. 604-608.

HARSÁNYI, D. - SZÁNTÓ, SZ. - TOTTH, G. 2014. A hazai borászatok marketingorientációja. In Alkalmazott tudományok I. fóruma: konferenciakötet. Budapest : Budapesti Gazdasági Fôiskola, 2014, pp. 305-324.

LEHOTA, J. - KOMÁROMI, N. - SZABÓ, Z. 2004. Marketing stratégiai típusok és csoportok szerepe, valamint a magyarországi borászatok. In Gazdálkodás, vol. 48, no. 3, 2004, pp. 13-25. p.

MAGDA, R. 2012. Economic questions of land usage - scarcity, sustainability. APSTRACT

MAGDA, R. 2013. Difficulties in sustainability and land utilisation. In Visegrad Journal on Bioeconomy and Sustainable Development, vol. 2, 2013, no. 1, pp. 15-18.

Molnár, E. 2007. A szekszárdi és a villányi borvidék összehasonlító marketingelemzése. PhD értekezés: Kaposvár, 2007, 1-206 p.

NAGY-KOVÁCS, E. - VARGA, T. 2010. Ártranszmisszió a szőlő-borvertikum piaci szereplöi között. In XII. Nemzetközi Tudományos Napok, Gyöngyös, 2010, pp. 528-535.

SIDLOVITS, D. - KATOR, Z. - BRAZSIL, D. 2012. A legújabb tendenciák a világ borpiacán. In Agrofórum, 2012, december, pp. 6-10.

SIDLOVITS, D. - KATOR, Z. 2015. Borpiaci helyzetkép. In Agrofórum Extra, 2015, no. 61, pp. $124-126$.

TOTTH, G. 2006. Marketing együttmúködések az élelmiszergazdaságban. A közösségi agrármarketing perspektívái és lehetóségei Magyarországon. In EU Working papers 3, 2006, pp. 53-62.

TOTTH, G. 2007. A közösségi marketing lehetőségei a kiegyensúlyozott táplálkozásra irányuló kommunikációban. In Élelmiszer, táplálkozás és marketing, vol. 4, 2007, no. 1, pp. 25-31.

\section{Contact address}

Dr. Pallás Edit llona, PhD, Eszterházy Károly Egyetem, Gyöngyösi Károly Róbert Campus, H-3200 Gyöngyös, Mátrai út 36, Tel: +36 3027884 79, e-mail: pallas.edit@uni-eszterhazy.hu 